\title{
DID RECENT TRENDS IN WORLD SOCIETY MAKE MULTINATIONAL CORPORATIONS PENETRATION IRRELEVANT?: LOOKING BACK ON VOLKER BORNSCHIER'S DEVELOPMENT THEORY IN THE LIGHT OF RECENT EVIDENCE*
}

\author{
Arno Tausch \\ Universität Innsbruck, Austria. E-mail: Arno.Tausch@bmsg.gv.at \\ *The opinios expressed in this article are strictly his own private academic opinions in the \\ framework of his venia docendi, and do not necessarily reflect the opinions of the Austrian \\ Government.
}

Recibido: 13 Noviembre 2004 / Revisado: 12 Diciembre 2004 /Aceptado: 15 Enero 2005 / Publicado: 15 Febrero 2005

Resumen: This article first investigates the determination of 14 indicators of development in 109 countries with complete data based on MNC penetration on development in the 1990s and beyond, with such "new" indicators as "Islamic culture" or "adherence to the Washington consensus". A consequence of the "dependency" analysis of this essay is the realization that a reliance on foreign capital in the short term also in the 1990s might bring about positive consequences for employment but that the long-term negative consequences of dependence in the social sphere, but also for sustainable development strategies for years to come. EU membership in the world economy fails to have sufficiently enough dynamic effects and its democratic deficits become ever more clears. The empirical record speaks a clear language in favor of Islamic democracy and against those in the West that attempt to treat Islamic cultural heritage as a general development burden. It should be also clear that a reliance on the "Washington Consensus" alone will not "fix" the performance of countries beyond a better and more predictable "development stability".

Palabras Clave: development theory, indicators of development, multinational corporations, Volker Bornschier, world society.

\section{INTRODUCTION}

ecent debates about globalization among decision makers and social scientists

$\mathrm{R}$ have coined the term that social scientists should be "pathfinders of globalization". A good segment of the international social scientific community would be in accordance with such a roledescription, while an equally important and growing segment of the social scientific community would vehemently oppose the basic axioms of globalization in its present form.

Volker Bornschier, throughout the 1970s, 1980s, and beyond, has been a critical voice on the long-run detrimental effects of transnational penetration on the host countries in world capitalism, thus enormously enriching earlier work on dependency theories, pioneered by Peter Heintz and the Latin American "dependency school". His theoretical and empirical developments made "dependency theory" truly global and linked it up to the evolving world system school, and by his networking and collaboration -especially with Christopher Chase Dunn- firmly entrenched the "quantitative approach" in the world system school. His later work, related to the long cyclical fluctuations in the world economy, has shown that instability is also an overwhelming element in the historical evolution of capitalism, and that the world would need a new social contract similar in its encompassing nature to the one that shaped the world after the Great 
Depression in the 1930s. Bornschier, as a true European and citizen of this world, has always asked himself what the alternatives are, and he put high hopes into the European Union as an alternative, more "social" pole in the world economy.

The spirits of our time are different, however. On the one hand, the idea that only by strict adherence to the canon of neo-liberal doctrine, a country will be able to achieve economic growth. To put it bluntly: do not worry about dependency and inequality, two cornerstones of Bornschier's scientific work, but concentrate on economic growth. Conventional wisdom of the "Washington Consensus" has it that it is always the periphery or semi- periphery country that got it all wrong during a crisis, like in East Asia, Russia or recently in Turkey and that a good combination of economic freedom, privatization, tight monetary policies and above all private foreign direct investment will "fix" it, once the forces of the market are properly at work.

The "Washington Consensus" has been summarized by Raffer $^{1}$ as to represent the following policy priorities:

1. Fiscal discipline: a primary budget surplus of several percent of GDP

2. Public expenditure priorities: defined as re-directions of public expenditures towards fields with high economic returns such as primary health and education

3. Tax reform: cutting marginal tax rates

4. Financial liberalization: moderately positive real interest rates and the abolition of preferential interest rates (such as for developmentally useful or socially demanded projects)

5. Exchange rates: unified and competitive

6. Trade liberalization: abolishing quotas (replacing them by tariffs) and reducing tariffs to a uniform low level within three to ten years.

7. Foreign direct investment: equal treatment with domestic firms. The World Bank calls this the elimination of barriers. This principle is also enshrined in the WTO treaties

8. Privatization

9. Deregulation: abolishing regulations aiming at achieving developmental or social aims

10. Property rights: must be guaranteed
Today's counter-position, advanced by globalization critics, environmentalists, liberation theologians of all denominations, and -most recently- dissidents from the once homogeneous neo-liberal camp would hold that unfettered globalization increases the social gaps between rich and poor both within countries as well as on a global scale. Most of the adherents of this camp would share the view proposed by Cornia and Kiiski that income distribution in the world system has worsened during the period of globalization.

The Latin American social scientist Osvaldo Sunkel first proposed in his essay Transnational capitalism and national disintegration (in Latin America) the still provocative thought that transnational investment and integration might go hand in hand under certain conditions with an increasing relative social polarization between rich and poor in the host countries of the evolving transnational system and on the international level ${ }^{2}$.

The other most visible preoccupation of comparative social science in the 1990s and beyond is associated with the effects of cultural and cultural patterns on the chances of development. Dramatic shifts in the centers of gravitation in the world economy from the Atlantic basin to the Pacific region and the stagnation that many observers diagnosed in large parts of the Middle East and North Africa tended to underline the relevance of Samuel Huntington's all too well known emphasis on culture.

While debates abound, hard-core social scientific evidence on the contradictory effects of globalization is needed more than ever before.

\section{THEORIES EXPLAINING BACKWARDNESS AND DISARTICULATION}

After the "ultimate triumph" of the market economy on a global scale (Fukuyama) as the result of the collapse of Communism in Eastern Europe, an intensive debate about the development prospects of Europe's Southern and Southeastern neighbors set in.

On a global economy level, neo-liberal authors like Barro; Barro and associates; Crafts; Dadush and Brahmbatt; Dollar and Kraay and Weede generally tend to think that with the establishment of "economic freedom" positive 
patterns of development will prevail in practically all countries.

Cultural theories of development tend to stress that at present development perspectives for the large region between Morocco in the West and Iran in the East are not good. Their principal spokesperson today is Huntington, but also such diverse sources as the UNDP's Arab Human Development Report (2002) or the World Bank's MENA Report (2002) tend to highlight the pretended various socio-religious development constraints in that region. While the UNDP stresses the lack of democracy, human resource development and gender equality as the main development blocks, the World Bank highlights the negative heritage of "Arab Socialism" or past state sector influence.

Dependency authors by contrast explain backwardness and stagnation by the evergrowing dependent insertion of these countries into the world economy. Starting with the writings of Perroux, Prebisch and Rothschild in the 1930s, their leading spokespersons, like Addo; Baran; Bello; Cardoso; Cordova; Cordova and Silva-Michelena; Dubiel; Feder; Flechsig; Frank; Frank and associates; Froebel et al.; Gonzales Casanova; Griffin; Griffin and associates; Kent; Linnemann and Sarma; Müller et al.; Raffer; Senghaas; Singer; So; Sunkel; and Woehlcke all would stress the unequal and socially imbalanced nature of development in regions that are highly dependent on investment from the highly developed countries. Short-term spurts of growth notwithstanding, long-term growth will be imbalanced and unequal, and will tend towards high negative current account balances. Many of these authors focused their attention on Latin America; their leading spokesperson in the Islamic world is the Egyptian economist Samir Amin.

Later world system analyses -that started with the writings of the Austro-Hungarian socialist Karl Polanyi after the First World War- tended to confirm and expand this dependency argument. Capitalism in the periphery, like in the center, is characterized by strong cyclical fluctuations, and there are centers, semiperipheries and peripheries. The rise of one group of semi-peripheries tends to be at the cost of another group, but the unequal structure of the world economy based on unequal exchange tends to remain stable. Authors from the world system approach, like Arrighi; Arrighi and associates; Beaud; Bornschier; Chase-Dunn; Chase- Dunn and associates; Frank and associates; Goldfrank; Goldstein; Hopkins; Hopkins and Wallerstein; Kiljunen; Modelski; Raffer; Ross and Trachte; So; Tausch and associates; Walker; and Wallerstein tended to discard the "culturalist" explanations, offered by Huntington, and rather would support the argument that world economic position, and not culture, determines conflict. Wallerstein comes clearly up in defense against demonizing the Arab/Islamic world and thinks that opposing forces against the present world order will increase ${ }^{3}$.

Dependency and world system theory generally hold that poverty and backwardness in poor countries -like the Islamic world- are caused by the peripheral position that these nations have in the international division of labor. Ever since the capitalist world system evolved, there is a stark distinction between the nations of the center and the nations of the periphery. Former Brazilian President Fernando Henrique Cardoso, when he was still a social scientist, summarized the quantifiable essence of dependency theories as follows:

- there is a financial and technological penetration by the developed capitalist centers of the countries of the periphery and semi-periphery

- this produces an unbalanced economic structure both within the peripheral societies and between them and the centers

- this leads to limitations on self-sustained growth in the periphery

- this favors the appearance of specific patterns of class relations

- these require modifications in the role of the state to guarantee both the functioning of the economy and the political articulation of a society, which contains, within itself, foci of inarticulateness and structural imbalance

A rising degree of monopolization in the leading center countries over time determines that, in order to keep the share of wages at least constant, a rising exploitation of the raw material producers sets in to offset the balance. There is a massive, internationally published evidence that speaks in favor of dependency theory. However, it would be wrong to portray dependency simply in terms of $\mathrm{MNC}^{4}$ penetration, and to neglect other aspects of that relationship. Such authors as Singer and Tausch have put emphasis on the resource balance as an indicator of the weight of foreign saving. Other 
formulations of dependency insisted on 'unequal exchange' which, according to one such formulation, hampers development (i.e. double factorial terms of trade of the respective country are $>1.0)^{5}$. Labor in the export sectors of the periphery is being exploited, while monopolistic structures of international trade let the centers profit from the high prices of their exports to the world markets in comparison to their labor productivity.

Neo-dependency and world system schools ${ }^{6}$ would fear in addition that the most recent tendencies of world capitalism will strongly work against high female employment and create female unemployment, and they would especially expect two hypotheses to hold

1. transnational capital marginalizes female labor power;

2. the dynamics of growth turn away from those countries, where women still have a strong position on the labor market.

The measurement scale, compatible with such hypotheses, would be the share of women in total employment and its trade-off with growth rates. The gender empowerment indicator series, first developed by the UNDP for the UNOWomen-Conference in Beijing 1995, provides a further testing ground for the different feminist social theories of world development.

However, neo-liberal thought would caution against such conclusions. Feminism per se might positively affect development patterns, but it might also work like a 'distribution coalition' that tries to influence -like all distribution coalitions - the results of the market via political pressure. Instead of changing the sexist distribution of human capital endowments, and thus changing the "starting capital" of women in society, feminism, the argument would say, tries to directly influence distributive relations via politics alone. The result could be -like with any distribution coalition- long-run stagnation and worsening income and other inequality.

Our theory has to be qualified in one important further respective. Militarism will under certain circumstances be a 'substitute' for a Keynesian strategy and might have positive consequences for employment, and hence, perhaps also distribution issues. Apart from that, it is not entirely clear whether -like it or not-a negative short term or middle term positive Keynesian relation between militarism and economic growth is to be ruled out entirely. Earlier research by Tausch (1993-2002) replicated some of the surprising findings by Weede in this respect.

Other schools of thought (Holzmann et al.; European Roundtable of Industrialists) have stressed recently the importance of pension reforms in a globally aging society as a determinant of growth and development. Aging societies and inadequate pension systems, and not culture, economic freedom or dependency alone, are to blame for the negative development perspectives in many leading capitalist countries. Without adequate pension reform, aging will be an increasing burden on the comparative growth and development perspectives of the aging richer nations.

Ever since the writings of Colemann (1965), also education should be mentioned among the determining variables of the development performance of a country. Education and human capital formation figure prominently in the "Human Development Reports" of the United Nations Development Programme as variables, which determine positively the development outcome. For the UNDP it has been self-evident over the last decade that gender empowerment and the re-direction of public expenditures away from defense will positively contribute to a positive development outcome.

However, neo-liberal thought would caution against such premature conclusions. Public education expenditures are still public expenditures, and it is entirely conceivable that in the long run public education expenditures might negatively affect the development chances of a society, not because they are education expenditures, but because they are still public expenditures. For such a theoretical understanding, University reform and University privatization would be important political steps to achieve a more viable development.

\section{DEVELOPING THE RESEARCH DESIGN}

So it is time to look anew at the evidence, empirically first presented by Volker Bornschier and his school for the 1960s, 1970s and early 1980 s, in a contemporary, comparative and multi-dimensional perspective. Development means more than ever: social development, economic development, ecological development, gender empowerment, and the development of democracy and civil society. It should be clear that the logic of the 1980s, the 1990s and beyond obey to another logic (the logic of the Aphase in a Kondratieff cycle) than the logic analyzed by Volker Bornschier in his path- 
breaking works in the 1970s and 1980s. The almost unlimited number of empirical studies on peripheral capitalism and development on a world level in the B-phase of the Kondratieff cycle from 1965 onwards go back, in a way, to the classic essay published by Johan Galtung in the Journal of Peace Research in 1971. For Galtung, income inequality, and hence, relative poverty in the nations of the world system is linked to trade partner concentration of the peripheral country and a trade structure that relies on the exports of raw materials and the imports of finished products. Bornschier, ChaseDunn, and their school later on reformulated the argument $^{7}$ : not only income inequality, but also long term economic growth are being negatively determined by dependency from transnational capital, to be measured by a weighted share of transnational investment penetration per the economic and demographic size of a nation. Later essays extended the argument to other indicators of human well-being, the environment as well as democratic stability ${ }^{8}$. Macroquantitative analyses modeled around the dependency/world system school generally have confirmed dependency arguments. According to these quantitative data analyses, there are powerful influences at work, which cause inequality and external imbalances in the periphery. Flagship essays and book publications of this school were written among others by Beer and Boswell; Birdsall; Bornschier; Bornschier and associates; Boswell; Boswell and associates; Bradshaw; Bradshaw and Huang; Bullock and Firebaugh; ChaseDunn; Chase-Dunn and associates; Crenshaw; Delacroix and Ragin; Dixon; Dixon and Boswell; Evans and Timberlake; Fiala; Firebaugh; Juchler; Kentor; London; London and Robinson; London and Ross; London and Smith; London and Williams; Moaddel; Muller; Muller and Seligson; Nollert; Nollert and Fielder; Ragin and Bradshaw; Robinson and London; Rubinson; Russell; Tausch; Tausch and associates; Timberlake and Kantor; Timberlake and Williams; Trezzini and Bornschier; and Van Rossem.

There has been a tendency in more recent crossnational research to focus not only on such variables as economic growth, income inequality and a few other indicators of social well-being, but to interpret "well-being" more widely to include also democracy, the environment, gender inequality and human development. Research results by Alderson and Nielsen; Beer; Bullock and Firebaugh; Burns et al.; DeSoysa and Oneal; Dixon, Fain et al.;
Firebaugh and Beck.; Firebaugh; Hertz et al.; Kick et al.; Korzeniewicz and Moran; London and Williams; Meyer; Shen and Williamson; Shin, Smith; Tausch; Ward; Wimberley; and Wimberley and Bello in general terms indicate that there is reason to believe that the march of global capitalism not only negatively affects the distribution of economic values in the world system, but also of democracy, human development, gender equality and the quality of the environment.

Our concept of dependence at least includes three dimensions:

- unequal exchange

- MNC penetration

- the resource balance.

The analysis of development patterns in the 1990s and beyond is complicated by the fact that capitalism develops not smoothly, but with very strong and self-repeating ups and downs, called cycles. Our choice of the time perspective starts from well-known empirical research results of Joshua Goldstein, Volker Bornschier, and Luigi Scandella on this issue ${ }^{9}$. Cyclical fluctuations have also a profound effect on cross-national comparisons of economic growth and societal development in the medium and long run. What could have been spectacular long-run growth, in the end might turn out to be just a short run cyclical spurt after a long recession. For that reason, we include "development stability" among the dependent variables of our analysis.

Cycle time plays, as we already stated, an important role in our approach. Arrighi's thought is especially worthwhile mentioning here: that the logic of accumulation on a world scale shifts along time, and that we again witness during the 1980s and beyond a deregulated phase of world capitalism with a logic, characterized -in contrast to earlier regulatory cycles- by the dominance of financial capital. Arrighi further teaches us that even a century can be a 'short run' in the evolution of world capitalism. For Arrighi, there are signal crises of world capitalism (the usual Kondratieff depressions), and there are terminal crises of the world system, like the great crash of the early 1340 s, which marked the beginning of the Genoese age, the 1560s, which marked the beginning of the Dutch era, the 1750s and 1760s, which marked the beginning of the British era, and the 1930s, which were the terminal crisis of British world capitalist dominance. Regulation can be successful, like after 1560, and 1930, and 
deregulation can be successful, like after 1340 , 1760 , and -most probably- the 1980s.

\section{QUESTIONS OF MEASUREMENT OF THE MULTIVARIATE ANALYSIS}

The choice of the 109 countries was determined by the availability of a complete data series for the independent variables (if not mentioned otherwise, UNDP data):

- $\%$ population, aged $>65 \mathrm{y}, 1998$

- $\%$ women in government, ministerial level

- (I-S)/GDP (calculated from UNDP; investments minus savings per GDP)

- the absence of economic freedom (Heritage Foundation and Wall Street Journal website for economic freedom, 2000. The indicator is ranked from 1.30 -Hong Kong, best country, to rank 161worst country, North Korea, indicator value 5.0)

- EU-membership

- Islamic conference membership (OIC website)

- $\quad \ln ($ GDP PPP pc)^2 (natural log GDP per capita in real purchasing power parities)

- $\ln$ (GDP PPP pc) (natural log GDP per capita in real purchasing power parities)

- military expenditure as \% of GDP

- MNC PEN 1995 (UNCTAD)

- public education expenditure per GDP

- unequal exchange (calculated from UNDP, concept: 1/ERDI; exchange rate deviation index)

The following dependent variables were used; with pair wise deletion of missing values each time determining the number of countries entering into the 14 final regression equations:

- $\%$ people not expected to survive age 60

- $\mathrm{CO} 2$ emissions per capita

- development stability (year with highest real income minus year with lowest real income) since 1975 (calculated from UNDP)

- ESI-Index (Yale/Columbia environment sustainability index project website)

- Factor Social Development ${ }^{10}$ (calculated from 35 UNDP social indicators, SPSS factor analysis)

- female economic activity rate as $\%$ of male economic activity rate

- female share in total life years (calculated from UNDP - share of female life expectancy in the sum of male and female life expectancy)

- GDP output per kg energy use ("ecosocial market economy")

- GDP per capita annual growth rate, 1990-98

- human development index

- life expectancy, 1995-2000

- Political rights violations

- share of income/consumption richest $20 \%$ to poorest $20 \%$

- unemployment (UN social indicators website)

Our presentation of the variables used in the analysis will be kept to a minimum ${ }^{11}$. Among the dependent variables, we just mention MNC penetration, unequal exchange and the resource balance as the three "master variables" of dependency. Unequal exchange is strongest in the periphery, and weakest in the centers, with the semi-periphery showing medium levels of exposure to unequal exchange. Foreign saving, for its turn, is strongest in many parts of Latin America, Southern Africa, in the "new Europe" and in China and in several countries of Southeast Asia. In general terms, we observe today high levels of MNC penetration in the "dominion economies" like Australia and Canada, in Western Europe, in some parts of Eastern Europe, in Central Asia, other parts of the former USSR, in many parts of Latin America, Southern and Western Africa, in Egypt, in Tunisia, and in China and Southeast Asia.

During the $1990 \mathrm{~s}$, penetration by transnational capital dramatically increased in many parts of Europe (especially in what was described by Donald Rumsfeld, US Secretary of Defense, recently as "the new Europe"); in eastern Latin America, in Southern Africa, in Central Asia and in South and Southeast Asia. However, there was a dramatic decrease of MNC penetration in most countries of the Arab world during the second half of the 1990s. Among the dependent variables perhaps only the environmental stability index might be not so well known in the macro-quantitative research community. The ESI Index is a measure of the overall progress towards environmental sustainability and was developed for 142 countries. ESI scores are based upon 20 core indicators, each of which combines two to eight variables for a total of 68 underlying variables. It is the first time in the research literature that a single yardstick of sustainable development has been developed. The picture for the region of the 
MENA countries is rather mixed, with Turkey being classified ahead of the United Kingdom and on an equal level with Italy.

We have to start here from the assumption that the basic tools of multivariate macroquantitative analysis in political science and sociology are known to the audience of this article (for further literature on the subject, see Achen; Clauss and Ebner; Huang; Jackman; Kriz; Krzysztofiak. and Luszniewicz; LewisBeck; Microsoft Excel; Opp and Schmidt).

A sophisticated re-analysis of the tendencies of world development in the 1990s should start from the assumption that the development level has a decisive, non-linear trade-off with subsequent development performance: poor countries increase rapidly their average life expectancy or economic growth and they quickly reduce their income inequality etc.

Social scientists interpreted this effect mainly in view of an acceleration of economic growth in middle-income countries vis-à-vis the poor countries and in view of the still widening gap between the poorest periphery nations ('havenots') and the 'haves' among the former Second and Third World ${ }^{12}$ :

- (Equation 1) development performance $=\mathrm{a} 1+\mathrm{b} 1 * \ln ($ PCItn $)-\mathrm{b} 2 *(\ln$ (PCItn))2

The same function is also applied to income inequality and the rest of our 14 indicators, following a famous essay published by $\mathrm{S}$. Kuznets in 1955. Growth and development accelerate with redistribution, and then stagnate. In general terms, we explain development performance by the following standard multiple cross-national development research equation:

- (Equation 2) development performance 1990 - end 1990s = a1 +- b1*first part curvilinear function of development level +- b2*second part curvilinear function of development level +b3...*transnational investment per GDP (UNCTAD) mid 1990s +- b4...*unequal exchange (1/ERDI) +- b5...* foreign saving +- b6..* military expenditures per GDP +- b7 ...* aging +- b8...* public education expenditures per GDP +-b9 * membership in the Islamic Conference +- b10 * European Union membership + - b11 * the absence of economic freedom
In the following, we will present our results about the effects of globalization in a multivariate perspective.

\section{$\begin{array}{llll}\text { THE FINAL RESULTS FOR } & 109\end{array}$ COUNTRIES}

Looking at the predictive power of Volker Bornschier's empirical analysis of world development in the 1970s and 1980s, one is led to the conclusion that several of his main points are as valid as today as they were twenty or thirty years ago. The cumulative economic and political power of transnational corporations in their host countries is -quite in line with monopoly capitalism theories developed by Baran, Kalecki and Rothschild- a long-term burden on the development paths of the periphery and the semi-periphery, short-run spurts of growth notwithstanding.

In general terms, several but not all aspects of the presented theories are confirmed, while other central assumptions of both the "Washington Consensus" and of its dependency theory counterpart are rejected. Also, theories so much en vogue in the 1990s and beyond about aging; feminist theories; human resource theories; military Keynesian theories/peace theories (i.e. theories maintaining that militarism has a very bad effect on long-run development); the contemporary globalization critique and international economic integration theories have to tally with both positive and negative effects of their key indicators on different measurements of social, environmental and economic welfare, indicating that the time of the "quick fixes" has definitely gone and that contemporary development realities are very complex indeed. It should be noted that in this and in the following presentations, we already considered duly that "good effects" are "good effects" and that "bad effects" are "bad effects" when presenting our results; i.e. a development strategy that increases, say, under 60 mortality rates, is a bad strategy and thus has negative effects.

Aging is part and parcel of the structure of industrialized societies, East and West. For Volker Bornschier ${ }^{13}$, the core countries grouped around the triad formed by the United States, Japan, and the European Union- have experienced successive waves of change marked by phases of ascent, unfolding, and decay of societal models, of which social security along the lines of the PAYGO-model formed and integral part. What according to Bornschier seemed stable and predictable in past decades 
came close to collapse or broke down entirely. A new order, with a fresh, basic consensus around an overarching set of norms that allows problems to be solved efficiently, has not yet crystallized. The role of social security would play an integral part in such a consensus.

Bornschier's seminal work ${ }^{14}$ Western Society in Transition should be especially mentioned in this context as an examination of the succession of societal models of the Western world and indications of its probable shape in the future. Bornschier's central question is how a social order does arise and why does it dissolve? What provides social cohesion? What makes society pro-gress? We can start from the safe assumption that the PAYGO systems -i.e. the pension systems institutionalized by, inter alia, Chancellor Bismarck in Germany- will be substituted in a majority of countries by funded and (partially) privatized schemes in future. But what consequence will this have for the rise and decline of nations, and for social cohesion? However much world systems research paid attention to the rise of the social welfare state in earlier periods, and to such phenomena as corporatism and Fordism, that characterized the long cycle of development from the 1930s to the $1980 \mathrm{~s}$, there is as yet no coherent and systematic approach to study the effects of what might become the substitution of one of the main features of the capitalist state in the center, the system of public social security, by a new and completely different system. Aging contributes to a generalized scarcity of labor, which in turn leads to improved distributive relationships between the rich and the poor. However, several negative effects must also be considered properly -especially the negative effects of an aging population structure on the process of human development, which is basically the dire consequence of unreformed pension systems ${ }^{15}$.

\section{aging \% population, aged $>65 y, 1998$}

- GDP output per kg energy use (ecosocial market economy) - positive effect

- female economic activity rate as \% of male economic activity rate - positive effect

- share of income/consumption richest $20 \%$ to poorest $20 \%$ (income redistribution) - positive effect

- unemployment (UN) (employment) positive effect

- $\mathrm{CO} 2$ emissions per capita (Kyoto) negative effect
- female share in total life years - negative effect

- $\%$ people not expected to survive age 60 (survival) - negative effect

- life expectancy, 1995-2000 - negative effect

- Factor Social Development - negative effect

- human development index - negative effect

Political feminism, a variable analyzed in Bornschier ${ }^{16}$ and systematically developed in the Zurich school by Than Huyen Ballmer-Cao, has an aggregate positive effect on many phenomena of human and ecological development, but it fails to transform political power into improved employment and distribution structures. This is due mainly to the process of distribution coalition formation, featuring so prominently in neo- liberal theories of economic growth (see especially, the writings of Weede).

\section{political feminism \% women in government, ministerial level}

- $\mathrm{CO} 2$ emissions per capita (Kyoto) positive effect

- female share in total life years - positive effect

- $\%$ people not expected to survive age 60 (survival) - positive effect

- life expectancy, 1995-2000 - positive effect

- Factor Social Development - positive effect

- human development index - positive effect

- GDP output per kg energy use (ecosocial market economy) - negative effect

- female economic activity rate as \% of male economic activity rate - negative effect

- share of income/consumption richest $20 \%$ to poorest $20 \%$ (income redistribution) - negative effect

- unemployment (UN) (employment) negative effect

As one of the three main indicators of dependency, the reliance on foreign savings eases the distribution burden against the poorer segments of society during the accumulation process, but it has several negative effects on a variety of other development processes, including the environment and political democracy. 


\section{foreign saving (I-S)/GDP}

- share of income/consumption richest $20 \%$ to poorest $20 \%$ (income redistribution) - positive effect

- $\mathrm{CO} 2$ emissions per capita (Kyoto) negative effect

- human development index - negative effect

- ESI-Index (sustainability) - negative effect

- Political rights - negative effect

The absence of economic freedom, a variable crystallizing the antipodes of dependency theory and being the master-variable of neo-liberal strategies, paradoxically enough, increases the rationality of the societal resource allocation and leads towards an improved development stability but it fails to resolve two basic issues: overall environmental stress and societal sexism in the employment sphere. Economic freedom creates opportunities for women as the more vulnerable group in society.

\section{absence of economic freedom}

- $\mathrm{CO} 2$ emissions per capita (Kyoto) positive effect

- GDP output per kg energy use (ecosocial market economy) - positive effect

- development stability (year with highest real income minus year with lowest real income) since 1975 - positive effect

- ESI-Index (sustainability) - negative effect

- female share in total life years - negative effect

- female economic activity rate as $\%$ of male economic activity rate - negative effect

Now we have to turn to a series of controversies, in which Bornschier was involved in the 1980s. Erich Weede, as is well known, challenged Bornschier's dependency approach by stating that militarization - measured by him by the variable "military personnel ratio"- is good for redistribution and economic growth. The political consequences of what at first glance looked like a quarrel between two schools of advanced, quantitative development theory only, were obvious, especially at the time when these controversies were published. Allende's government in Chile, that systematically questioned the relationships of dependency and provided even a refuge for many dependency theorists at the time from political persecution elsewhere, was deposed in 1973 by a military dictatorship practicing a neo-liberal growth strategy combined with high military outlays. South Korea and Taiwan surged ahead under the nuclear umbrella provided by the 7th US Fleet, and all had very large military establishments. Left-wing movements in Nicaragua and El Salvador, questioning dependencia were actively confronted by the Reagan administration in the US, that boosted military outlays as never before a government did in US history. Many governments in Europe, especially in European NATO countries, followed suit and dramatically increased military expenditures, while cutting back on social welfare. In the Eastern Bloc countries, the spiral of militarism more and more constrained consumption. The provocation by Weede was put on the table, and the controversy ensued. Looking back at the issues in the light of today's evidence, let us state this: Military expenditures do have a certain Keynesian effect but they contribute towards a worse environmental balance. Military expenditures lead towards a drying up of what Marxists term "the reserve army of labor", which, in turn, leads to a certain better social cohesion and employment gender balance. But militarized structures consume large amounts of fossil fuel, with advanced air forces especially contributing to that process.

- female economic activity rate as \% of male economic activity rate - positive effect

- share of income/consumption richest $20 \%$ to poorest $20 \%$ (income redistribution) - positive effect

- $\mathrm{CO} 2$ emissions per capita (Kyoto) negative effect

- GDP output per kg energy use (ecosocial market economy) - negative effect

And now, to Bornschier's master variable, MNC penetration. The author of the present study is well aware of the intricate questions regarding the measurement of this variable. Should we use today the available UNCTAD data series about MNC cumulated investments per GDP of host countries, or should we re-analyze the data series that many people regard as somewhat deficient? Should we introduce, as Bornschier tended to do then, weights for population size and size of the economy to control for the fact that small countries will always have a higher MNC penetration ratio, regardless of their development strategy, simply because of their size? Should we control for the skewness of the indicator by square-rooting or whatever the 
original data series? Are we not running, on the other hand, the risk of introducing GDP as a term in the equation on the explanatory side, when we want to explain precisely GDP growth? For the purposes of this essay we leave it at that, and are aware of the intricate methodological questions involved, and simply work with the original UNCTAD data series cumulated foreign direct investments per GDP of the host country. The results for the world of today are somewhat striking: MNC penetration contributes to an improved ESI Index and towards better female employment, but it has negative consequences for human survival and life expectancy.

The positive environmental effect might be a consequence of higher environmental standards of leading transnationals and the implementation of the European Union body of law (acquis communautaire) in the host countries of the heavy transnational investments in East Central Europe. In the wake of the perspective of EUmembership, massive investments by the transnationals poured into the region. But it should also be emphasized that the ESI indicator is not free from controversy ${ }^{17}$, and must be cross- checked with other, more direct measures such as $\mathrm{CO} 2$ consumption per capita etc.

In addition, an interesting phenomenon worthy of further research is the interconnection between decaying public services, decaying public transport and decaying public health services in the host countries of transnational investment on the one hand and the strategic policies of transnational corporations on the other hand, concentrated on the private sector, private transport, private medical services and the private automobile. The strengthening triple alliance between the MNCs, local capital and the state is a net result of the globalization process, and it still has dire social consequences as well.

\section{dependency on foreign capital MNC PEN 1995}

- female economic activity rate as \% of male economic activity rate - positive effect

- ESI-Index (sustainability) - positive effect

- $\%$ people not expected to survive age 60 (survival) - negative effect

- life expectancy, 1995-2000 - negative effect
Human resources and human development investments ever since the publication of the first United Nations Human Development Reports in the early 1990s are regarded as the key towards a socially equitable and sustainable development. However, as often happens in development theory, the early optimism regarding the effects of one variable has soon to be qualified.

There are very surprising clear-cut negative interactions between public education expenditure and an eco-social market economy and political democracy. Positive effects exist as well, but they are not statistically significant. A plausible intervening variable, which we did not as yet consider in our investigation, could be the years of experience of a country as a centrally planned economy.

\section{public education expenditure per GDP}

- GDP output per kg energy use (ecosocial market economy) - negative effect

- Political rights - negative effect

Unequal exchange has the most clear-cut negative results of all dependency indicators on the process of development, as understood in this investigation; especially on democracy, the environment, gender justice and employment. The positive effect on income redistribution has to be seen in the context of the siphoning-off of the surplus value from periphery countries by the mechanisms of dependency that reduces the share of the richest $20 \%$ in total income distribution.

\section{unequal exchange}

- share of income/consumption richest $20 \%$ to poorest $20 \%$ (income redistribution) - positive effect

- GDP output per kg energy use (ecosocial market economy) - negative effect

- Political rights - negative effect

- female economic activity rate as \% of male economic activity rate - negative effect

- ESI-Index (sustainability) - negative effect

- $\mathrm{CO} 2$ emissions per capita (Kyoto) negative effect

- female share in total life years - negative effect

- unemployment (UN) (employment) negative effect 
There are very diverse views nowadays on the European Union. Bornschier reiterated throughout the 1990s and beyond his optimism regarding the Union. But as a recent paper, published in the journal Parameters of the US Army maintains:

«Still, there are those on both sides of the Atlantic who believe that the European Union, as an old-fashioned socialist bureaucracy, is 'fundamentally unreformable' and also culturally hostile to the United States».

There is a wide range of literature now available that highlights the negative effects of European integration in a globalized world economy ${ }^{18}$. In the present research design, the most considerable effect is the negative trade-off between EU membership and political democracy, once you control for the other intervening variables that together explain jointly $66.1 \%$ of political rights violations.

\section{EU-membership}

- Political rights - negative effect

Our results about the European Union might be considered more provocative still, when we also consider that -contrary to popular assumptionsmembership in the Islamic Conference is not an impediment against political democracy. Our results clearly contradict many of the expectations inherent in the writings of Professor Samuel Huntington. 4 development indicators -2 for the environment, 1 on human development, and 1 on democracy- are positively and significantly determined by membership in the Islamic Conference, once you properly control for the effects of the other influencing variables. However, gender justice and redistribution remain the "Achilles heel" of today's members in the Islamic Conference, strengthening the cause of those who advocate like in the United Nations Arab Human Development Report- more social inclusion and more gender justice in the region.

\section{Islamic conference membership}

- Political rights - positive effect

- GDP output per kg energy use (ecosocial market economy) - positive effect

- $\mathrm{CO} 2$ emissions per capita (Kyoto) positive effect

- life expectancy, 1995-2000 - positive effect

- share of income/consumption richest $20 \%$ to poorest $20 \%$ (income redistribution) - negative effect
- female economic activity rate as \% of male economic activity rate - negative effect

The well-known acceleration and maturity effects of development have to be qualified in an important way. Ever since the days of Simon Kuznets, development researchers have applied curve-linear formulations in order to capture these effects. However, the results for equation 1 above are not as clear-cut as one might have expected; and -in addition- the direction of the influence does hardly correspond with the equation. The curve-linear function of growth, being regressed on the natural logarithm of development level and its square, is sometimes called the "Matthew's effect" following Matthew's:

«For whosoever hath, to him shall be given, and he shall have more abundance: but whosoever hath not, for him shall be taken away even that he hath».

Social scientists interpreted this effect mainly in view of an acceleration of economic growth in middle-income countries vis-à-vis the poor countries and in view of the still widening gap between the poorest periphery nations ('havenots') and the 'haves' among the semi- periphery countries. Their hypothesis is only partially confirmed here - there is no significant acceleration at low levels of development, but a significant econonmic growth stagnation/saturation effect. The first expression $-+\mathrm{b} 1 * \ln (\mathrm{PCI} t \mathrm{t})-$ yields the following results:

\section{acceleration effects development $\ln$ (GDP PPP} pc)

- female economic activity rate as $\%$ of male economic activity rate - positive effect

The second part of the "Kuznets-curve" -b2* (ln (PCItn))2- has today the following results:

\section{maturity effects development In (GDP PPP pc)^2}

- female economic activity rate as \% of male economic activity rate - positive effect

- life expectancy, 1995-2000 - positive effect

- share of income/consumption richest $20 \%$ to poorest $20 \%$ (income redistribution) - positive effect

- ESI-Index (sustainability) - positive effect 
- female share in total life years - positive effect

- human development index - positive effect

- Factor Social Development - positive effect

- GNP per capita annual growth rate, 1990-98 - negative effect

\section{IMPLICATIONS FOR POLICY}

Volker Bornschier's empirical, cross-national research can be summarized today in the sentence that uncritical reliance on the processes of globalization will not be the "quick fix" for the problems of development that contemporary theories pretend it to be. By far the most negative influence on development is wielded today by unequal exchange, followed by the aging process (especially without pension reform) and certain negative aspects of feminist distribution coalitions in society. By far the most positive effects on social, ecological and economic development come about by the maturity effects of development, followed by the positive aspects of feminism, the aging process and membership in the Islamic Conference.

With all the talk about dependency, globalization or the "Washington Consensus" notwithstanding, it is shown that feminism, pension reform, and the maturity effects of capitalism open up new horizons of future development debates. The variables

- political feminism \% women in government, ministerial level

- $\quad$ aging \% population, aged $>65 y, 1998$

- maturity effects development ln (GDP PPP $\mathrm{pc})^{\wedge} 2$

- unequal exchange

are far more relevant in explaining our 14 development dimensions than the traditional "stars" of the debate, the political and left and right, pro- and anti-globalization movements, culturalist development theories etc. notwithstanding. The variables

- Islamic conference membership

- economic freedom

- foreign saving (I-S)/GDP

- military expenditure as \% of GDP

- dependency on foreign capital MNC PEN 1995

- public education expenditure per GDP

- acceleration effects development $\ln$ (GDP PPP pc)

- EU-membership on the other hand do not have so many significant effects (insignificant effects $>50 \%$ ) as the "new" variables (insignificant effects $<50$ $\%$ ), which were analyzed in this article and which will determine future development outcomes in a decisive way.

Let us turn to the issue of Islamic development efficiency. The empirical record, presented in this essay, speaks a clear language in favor of Islamic democracy and against those in the West that attempt to treat Islamic cultural heritage as a general development burden. A careful reading of what theologians -most notably, also leading Christian experts on Islam among thempositively have to say on Islamic humanism and its interesting institutions of zakat and sadaqat is in stark contrast to the contemporary rhetoric of cultural warfare; basic Islamic institutions have enormously many positive aspects to offer to world development. A glance at the literature could easily convince anyone about the richness of Islamic social doctrine and Islamic social philosophy. Zakat is the first institution of social security in the world system. Payment of $21 / 2$ percent of savings of the zakat fund is one of the fundamental duties of a Muslim. The State is responsible to collect zakat and makes arrangements for its distribution; while sadaqat is paid at no fixed rate ${ }^{19}$.

Our evidence shows that the majority of Islamic countries transformed their "growth" much better to the benefit of "life quality" (average life expectancy) than most other societies around the globe.

At the same time, the UNDP data set shows that life expectancy as the most direct indicator of life quality in the world system has dramatically increased in the regions of the Middle East and in the Andean countries of Latin America, while in Southern Africa and in Eastern Europe there was a stagnation over the long period 19702000 .

Seen in such a way, the contrary of common beliefs is true: "Kemalism", "Arab socialism" and other "isms" were quite successful, while the "Washington Consensus" strategies put in place after 1989 in Eastern Europe and the former USSR proved to be one of the utmost development failures in human history.

At a time, when leading protagonists of the "Consensus" proclaim that growth is simply good for the poor, it is time to reckon by quantitative means the complicated relationships 
between growth and the social and ecological dimensions of growth.

It also emerges that the Islamic countries are among the best performers on our scale measuring exceptional human development increases in the world system (already taking into account past levels of human development).

Development is a contradictory and dialectical process. There is no single strategy, that has only positive results, and there is no strategy, that has only negative results. No single development theory today captures all these negative and positive effects that interact together. At this stage, perhaps, the question will arise -what are the real policy implications, then, of this kind of analysis? It should be clear that a reliance on the "Washington Consensus" alone will not "fix" the performance of countries beyond a better and more predictable "development stability". The most consistent consequence of the "dependency" analysis for which Volker Bornschier stood for many years is the realization that a reliance on foreign capital in the short term might bring about positive consequences for employment especially female employment- but that the long-term negative consequences of dependence in the social sphere, but also for sustainable development, outweigh the immediate, positive effects. Our three-fold empirical understanding of the process of globalization - reliance on foreign savings, MNC penetration and unequal exchange-, goes beyond the average analysis of the workings of dependency structures and shows how different aspects of dependency negatively affect development performance. The integration of the countries of the periphery into larger currency blocs -quite contrary to what the "Washington Consensus" has to say about "competitive currencies"- will be one of the most important tasks for international development strategies for years to come. Left for themselves in the capitalist world economy, the countries of the periphery and semiperiphery will always be victims of international currency instabilities. In the light of earlier published analyses, it is no surprise that "unequal exchange" (1/ERDI; ERDI being the exchange rate deviation index) is again established to be the most important dependency variable today, far more important in its negative effects on social and sustainable development than the UNCTAD data series on $\mathrm{MNC}$ penetration. European Union integration, this analysis again shows, on the other hand is not a quick fix for many of the social ills of the periphery and semi- periphery. The EU under present conditions fails to have sufficiently enough dynamic effects and its democratic deficits become ever more clear.

In terms of the size of the quantitative effects on the 14 dimensions of development under investigation here, it is shown that the new political structures associated with political feminism that substituted patriarchic structures inherent in practically all world regions for much of the 19th and the early 20th Century have a very considerable effect on the development outcomes of today. As we have outlined above, feminism in power -i.e. the share of women in positions of political decision making- achieves to transform many aspects of development, but, as other "distribution coalitions" before it, creates certain aspects of stagnation as well and thus is not free from the effects of the logic of "collective action" that is at the heart of the neo-liberal doctrine (see especially the works Olson and Weede). In the 21 st Century, the process of aging and the necessity of pension reform, closely linked to that process, also cannot be overlooked anymore. In our analysis, unequal exchange, aging, and political feminism achieve the majority of the significant effects on the 14 development dimensions under investigation, i.e. far more than the "master" variables of earlier debates, like "economic freedom" versus "MNC penetration". As has been argued elsewhere, globalization critics especially must start to look at pensions and pension funds seriously - because the way, in which you manage the savings of society for old age, you also manage technological innovation and world systems position in general ${ }^{20}$. It is also evident from the analysis presented in this article that Islamic culture is not a development blockade; on the contrary. Membership in the Islamic Conference has --ceteris paribus-- a very positive effect on political democracy, on life expectancy, and on our indicators of the Kyotoprocess and the eco-social market economy. Far from being a "religion of the Middle Ages" Islam has an important message for the $21 \mathrm{st}$ Century. It is to be hoped that socially progressive forces in the MENA countries will achieve a better monetary distribution of incomes and a better gender distribution of work in the societies concerned in thefuture.

It is shown in this article, that transnational integration is and remains to be a contradictory process that does not lead $1: 1$ to a greater amount of social cohesion and sustainable 
development in the host countries of transnational penetration. The role of the social scientist then will not be "pathfinders to globalization" but to become pathfinders for those millions, who will become marginalized by the process of social disintegration, that goes

\section{NOTAS}

${ }^{1}$ Cit. in Tausch, A. (ed.), Three Pillars of Wisdom: A Reader on Globalization, World Bank Pension Models and Welfare Society. New York, Nova Science, 2003, 305-323.

2 Sunkel, Osvaldo, "Transnationale kapitalistische Integration und nationale Desintegration: der Fall Lateinamerika", in Imperialismus und strukturelle Gewalt. Analysen ueber abhaengige Reproduktion. Frankfurt, Suhrkamp, 1972/1973, 258-315. Id., Capitalismo transnacional y desintegracion nacional en America Latina. Buenos Aires, Ediciones Nueva Vision, 1984.

3 Wallerstein, I., "Islam, the West and the world", Papers of the Fernand Braudel Center, 1998, [document on-line] Avalaible from Internet at: $<$ http://fbc.binghamton.edu/iwislam.htm $>$.

${ }^{4}$ MNC: Multinational Corporations.

${ }^{5}$ Vid. Amin, S., Unequal Development: An Essay on the Social Formations of Peripheral Capitalism. New York, Monthly Review Press, 1976; Tausch, A.; Köhler, G., Global Keynesianism: Unequal exchange and global exploitation. New York, Nova Science, 2002.

${ }^{6}$ Vid. Tausch, A.; Praeger, Towards a Socio-Liberal Theory of World vDevelopment. Basingstoke and New York, Macmillan/St. Martin's Press, 1993.

7 Vid. Bornschier, V.; Chase-Dunn, Ch. K., Transnational Corporations and Underdevelopment. New York, Praeger, 1985.

8 Id., "Technological Change, Globalization and Hegemonic Rivalry" in The Future of Global Conflict. London, Thousand Oaks and New Delhi, Sage Publications, 1999, 285-302.

9 Tausch, A.; 1998. Globalization and European Integration [book on-line] Avalaible from Internet at: $<$ http://csf.colorado.edu/wsystems/archive/books/ tausch/tauschtoc.htm $>$.

${ }^{10}$ Id., 2001. The European Union: global challenge or global governance? 14 world system hypotheses and two scenarios on the future of the Union[document on-line] Avalaible from Internet: $<$ http://www.uni-trier.de/zes/bd49.html $>$.

${ }^{11}$ The full data set, based on UNCTAD and UNDP data, is freely available as an EXCEL file from: $<$ http://www.gallileus.info/gallileus/members/m_TA $\mathrm{USCH} /$ publications/ $>$.

12 Tausch, A.; Hermann, P., Globalization and European Integration. New York, Nova Science, 2002.

${ }^{13}$ Bornschier, V., Western society in transition. New Jersey, Transaction Publishers, 1996. along and is part and parcel of transnational integration. Volker Bornschier is such a pathfinder, and let us state how grateful the critical development research community across the globe is for all his path-finding contributions.

${ }^{14}$ Ibid.

${ }^{15}$ Tausch, A., Three pillars..., op. cit.

${ }^{16}$ Bornschier, V., Western society..., op. cit.

17 "Keeping score - ESI - '2001 Environmental Sustainability Index' - Statistical Data Included". The Ecologist, April 2001. Avalaible from Internet at: $<$ http://www.findarticles.com/ cf_dls/ m2465/3_31/ 73040733 / print.jhtml $>$.

${ }^{18}$ For a survey of the literature and politometric evidence, see Tausch, A.; Hermann, P., Globalization..., op. cit.

19 See The Light of Islam website at $<$ http://home.swipnet.se/islam/articles/Non-

Muslim.htm>.

20 Tausch, A., Three pillars..., op. cit.', 20, 'The opinions expressed in this article are strictly his own private academic opinions in the framework of his venia docendi, and do not necessarily reflect the opinions of the Austrian Government. 